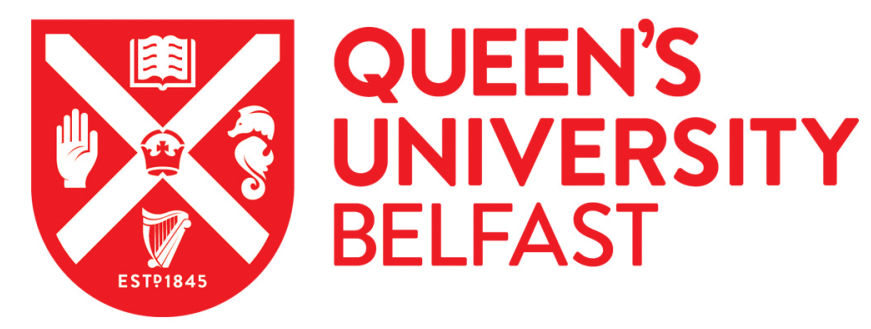

\title{
Undoing EU security through the art of failure: cinematic imaginations in/from the post-Yugoslav space
}

Deiana, M-A. (2020). Undoing EU security through the art of failure: cinematic imaginations in/from the postYugoslav space. Critical Studies on Security. https://doi.org/10.1080/21624887.2020.1799645

Published in:

Critical Studies on Security

Document Version:

Peer reviewed version

Queen's University Belfast - Research Portal:

Link to publication record in Queen's University Belfast Research Portal

Publisher rights

Copyright ( 2020 Informa UK Limited trading as Taylor \& Francis.

This work is made available online in accordance with the publisher's policies. Please refer to any applicable terms of use of the publisher.

\section{General rights}

Copyright for the publications made accessible via the Queen's University Belfast Research Portal is retained by the author(s) and / or other copyright owners and it is a condition of accessing these publications that users recognise and abide by the legal requirements associated with these rights.

Take down policy

The Research Portal is Queen's institutional repository that provides access to Queen's research output. Every effort has been made to ensure that content in the Research Portal does not infringe any person's rights, or applicable UK laws. If you discover content in the Research Portal that you believe breaches copyright or violates any law, please contact openaccess@qub.ac.uk. 
Title:

\title{
Undoing EU security through the Art of Failure: Cinematic Imaginations in/from the Post-Yugoslav space. Author details:
}

Maria-Adriana Deiana, m.deiana@qub.ac.uk

School of History, Anthropology, Politics and Philosophy, Queen's University Belfast

\section{Bio:}

Maria-Adriana Deiana is a lecturer in International Relations at Queen's University Belfast. Her research deploys feminist and other critical IR perspectives to examine the interrelated issues of war, peace, security. She has authored papers on gender politics, citizenship and feminist activism, as well as on the relationship between cinema, borders and affect in contexts shaped by conflict/international intervention. She has conducted research on the post- Yugoslav space, the politics of Northern Ireland, EU border politics and security. Her monograph titled "Gender and Citizenship: Promises of Peace in Post-Dayton Bosnia \& Herzegovina" was published by Palgrave in 2018.

\begin{abstract}
This paper makes a contribution to critical scholarship on EU b/ordering and ontological security. It deploys an aesthetic approach informed by decolonial scholarship and queer theory to critically examine the operation of EU security from the vantage point of BosniaHerzegovina, a site perennially relegated to the EU's dysfunctional periphery which has recently re-entered the spotlight in contemporary debates over the EU's border regime refracted through the Balkan route. Mobilising decolonial scholarship and queer theorising offers a provocative entry point to interrogate EU security as a regime of the normal that constitutes the EU as a coherent, stable and progressive self/space through the production of places that "fail" to be knowable according to its universalising norms. Such analytic reveals the stakes of being rendered a target of EU security for the communities that inhabit this site of b/ordering, while also making visible subjugated knowledges that are discarded and disqualified in normative narratives and practices. Aesthetic methods afford us a powerful entryway to uncover such knowledges. I propose a conceptual reading of two local documentary films premiered at the Sarajevo Film Festival that unsettle dominant mappings of the region. I argue that aesthetic knowledges produced through these films contain alternative, more pluralist and creative ways of being in the world that defy progressive temporalities and neat b/ordering, exposing the limits of EU security.
\end{abstract}

Keywords: EU, Security, Queer IR, Border Thinking, Bosnia, Cinema, Introduction 
From its inception in the Bosnian war, the Sarajevo Film Festival (SFF) has now become an international event devoted to artistic reflections on the war, the showcase of regional film industries and the promotion of cultural cooperation within and beyond the post-Yugoslav space (see also Kotecki 2014). At the interface between cultural politics, economic interests and the region's legacy of postsocialist and post-conflict transformation, I was drawn to the Festival as a productive thinking space (Bleiker 2017) to reflect on key border-making processes and imaginaries at stake internally to Bosnia, in the wider Post-Yugoslav region, and within EUrope. ${ }^{i}$

In the summer of 2015, the SFF reflected complex intersections between border politics, conflict histories and imaginaries of the region and the contemporary militarised spectacle of EU border security. Its $21^{\text {st }}$ edition, in fact, coincided with the unfolding of interlocking tensions within the EU border security regime. Refugees and migrants fleeing war, instability and hardship continued to attempt (and often tragically fail) to reach the shores of Italy and Greece. In that summer, some began their journey to access the EU on foot through the Balkan route only to be met by security forces, detentions centres, teargas and barbed wire fences. The media spotlighted the Balkan route through images of migrants and refugees lined up, stopped at border checks, finding shelter in make-shift accommodation, as well as of citizens who had organised solidarity movements, bringing in the same frame parallel histories of war, loss and displacement from different, yet connected, "peripheries"(see also Baker 2018). Having been a target of EU security as a space of intractable conflict, ethnonational division, organised crime and illiberal democracy, the region became the epicentre of the so-called EU refugee crisis as a route of illegal migration and, again, a threat to EU stability.

Echoes of the violent aesthetics of EU border politics, present and past, entered the Sarajevo Film Festival both explicitly and in more subtle ways. Not only did the festival programme include a special series of screenings that evoked current political events under the title "Taking down the fences". Border narratives were also evoked through the visual knowledges produced by two documentaries included in the series, Jasmila Žbanić's One Day in Sarajevo (2015) and Vladimr Tomic's Flotel Europa (2015). Although seemingly unrelated, the context of their screening activated parallels between the local experiences and imagination related to Sarajevo as a site of warfare depicted in the films and the 'hardnose reality' (Bleiker, 2017) of EU border security that was unfolding. Developing a conceptual reading of the films I complicate the perennial production of Bosnia and the SEE region as a space that fails to live up to EU norms of peace and security. I argue that combining decolonial mapping of the Southeast Europe region, queer scholarship on failure and the notion of border aesthetics (Schimanski and Wolfe 2017) opens a productive 
terrain to analyse the violence of EU border politics, past and present, and expose the fantasy of EUrope as a coherent space of progress, peace and democracy. Crucially, I suggest that the aesthetic knowledges produced through the films contains alternative, more pluralist, ways of being the world that are masked in taken for granted narratives of EU peace and security.

The article proceeds as follows. I begin by situating the production of Bosnia-Herzegovina as a dysfunctional EU periphery within the literature on EU b/ordering and ontological security. Through this lens, b/ordering is an instrument that secures the EU's identity as a stable and progressive political community by mobilising its foundational myth of Europe's long peace. Building on decolonial scholarship, I show how, from the vantage point of Bosnia-Herzegovina, the promises of Europeanisation as a peace project and its attendant b/ordering logic are imbued with figurations of failure. I discuss how combining decolonial mappings with queer insights on failure can unearth complexities and possibilities at this site that recover subjugated knowledges and dispel the founding myths of Europeanization. Outlining the article's aesthetic approach, I Illustrate how the films under examination enact powerful cinematic imaginaries that disorder and disturb the borderlines of this cartography, offering glimpses of life otherwise.

\section{Producing Bosnia-Herzegovina: EU b/ordering and its Aesthetics of Failure.}

Narratives of the European Union as project of peace, progress and liberal democracy underpin its shifting configurations as a political community and geopolitical space. Mobilised in externally facing policies to constitute the EU's identity as a global security actor, these normative mappings function to legitimise EU authority in preventing conflict and promoting international peace and security outside its borders. Scholars working with the notion of ontological security conceptualise such narratives as mechanisms of anxiety management that seek to produce closure, coherence and a stable EU "self" in response to key stressors and existential crises within and outside its borders (Kinnvall, Manners, and Mitzen 2018; Manners and Murray 2016). In this scholarship, the EU is interrogated as an anxious community that seeks to constitute and, in some instances, securitise its identity through temporal linearity, binary logics and b/ordering(Mitzen 2018; Della Sala 2018; Subotic 2018; Rumelili 2018). EU peace and security narratives thus function as foundational myths that 'anchor" the EU's identity vis-à-vis a number of Others, variously conceived as targets of enlargement, peacebuilding and neighbourhood policies, and/or security threats that attempt to undermine its borders. Drawing on a postcolonial approach, Kinnvall highlights the inescapable violence in narratives of EUrope as a stable, linear and progressive project emerged from a conflictual past into a civilized present and future (Kinnvall 2016). From a postcolonial perspective, thus, the EU's foundational myths are irremediably haunted by the 
legacy of colonialism, fantasy of homogenous identities and bounded spaces (Kinnvall 2016; Bhambra 2017; Chakrabarty 2009). My contribution to existing literature seeks to both decentre and deconstruct the seemingly coherent and progressive ontology of EU peace and security from the perspective of Bosnia and Herzegovina $(\mathrm{BiH})$, a key site where the EU border/security regime meets the elusive promises of Europeanisation. I argue that combining post/decolonial scholarship and queer theory opens a productive terrain to examine the stakes of being rendered a target of EU security for the communities that inhabit this region. Crucially, such analytic enables us to question the very idea of EUrope as a knowable and singular space and the reproduction of liberal, masculinist and racialised ideas of subjectivity in the anxious labour that seeks to craft coherent narratives of the EU as whole self.

Critical scholars have questioned the aggressive promotion of the EU mission civilisatrice that projects the EU as normative political trajectory and ideal of community for the postYugoslav space and Southeast Europe (Horvat and Štiks 2012; Majstorović, Vučkovac, and Pepić 2015; Kušić, Lottholz, and Manolova 2019). Inspired by postcolonial and decolonial theory, a rich literature has worked to deconstruct dominant global imaginings of the SEE region ${ }^{\mathrm{ii}}$ framed through Eurocentric gaze and shaped by regimes of modernity and coloniality (Todorova 1997; Wolff 1994; Kovacevic 2009; Bjelic and Savic 2005; Choi and Deiana 2017; Kušić, Lottholz, and Manolova 2019). Building on and developing such insights, I suggest that the EU peace and security narratives of making Bosnia 'work for Europe' (Bialasiewicz 2011, 1) rely on a specific aesthetics that frames the region as a target of EU knowledge and intervention, whether framed as space of intractable conflict, ethnonational division and corruption, as a route for organised crime, illegal migration and external illiberal influences, and/or as candidate for enlargement. From the vantage point of Bosnia, peace is equalled with the neoliberal promise of EU membership and constructed as the (progressively achievable and measurable) outcome of making Bosnia a knowable and governable EU space (Haahr and Walters 2004). The so-called road into Europe is thus intrinsically linked to disparate technologies of discursive and material b/ordering that uphold the myth of the EU as a peace project and coherent political community.

At the same time, b/ordering reiterates its exclusion from the European project and space of liberal democracy on the grounds that Bosnian society and its democratic structures are not functional, not progressive, not European yet. Underlying the road into Europe are, thus, longstanding tropes of a dysfunctional and backward space that variously highlights BiH's failures while legitimising the EU's identity as a coherent political communityiii. In this narrative the EU emerges as a peace and security actor that can facilitate and provide a framework for conflict resolution, redemption, reform and, as an extension, progress toward the EU/futurityiv. The power of such promises endures even though, in its application to 
Bosnia's divisive and fragmented post-conflict institutional context, EU efforts to push for progress have largely resulted in an long-standing impasse whereby many of the parties that should enact the reforms deemed necessary for integration are indeed the very political elites benefiting from the status quo (Gilbert and Mujanović 2016; Gordy 2015) Peace and security through EU b/ordering gesture to potentially including $\mathrm{BiH}$ while also highlighting its unsuitability for membership due to lack of progress in redeeming itself. In other words, while evoking a linear and progressive exercise that would eventually lead to integration, EU b/ordering continuously works to entrap $\mathrm{BiH}$, its inhabitants and their complex lived experiences within a cartography of failure: BiH's failure to resolve its intractable problems and to diligently progress towards EU futurity.

Interrogating EU ontological security from the perspective of Bosnia and Herzegovina we begin to see the exclusionary logics and processes of Othering constitutive of narratives of Europeanisation as a peace project and its attendant b/ordering practices. As decolonial scholarship on the region attests, b/ordering here assumes the form of a constant deferral, producing Bosnia as (perennial) candidate, made to 'patiently wait in the ante-chamber of modernity'(Kušić, Lottholz, and Manolova 2019, 17), while obscuring its complex historicity and the interlaced everyday, embodied and affective afterlives it has produced. For the seemingly linear, coherent and progressive cartography of EU b/ordering, necessarily rely on the production of places, such as Bosnia, that cannot but "fail' to function according to taken for granted EU norms and imaginaries. I argue that deploying a decolonial and queer lens to interrogate the production of Bosnia as failure opens a productive route to recover interlaced experiences as subjugated knowledges that disrupt the ontological foundations of EU security and unearth alternative political possibilities at its limits through border thinking (Mignolo and Tlostanova 2006).

\section{Failure as Art : Queer (im)possibilities and the limits of EU ontological security.}

The intersection of post/decolonial theorising and queer scholarship offers a provocative entry point to think critically about the binary analytic and geotemporal figurations underpinning EU security and expose its limits. It is important to acknowledge that a key contribution of queer scholarship on security lies in examining the operation of heteronormative, cisgendered and racialised border practices and their effects in the everyday lives of queer folks (e.g. Shepherd and Sjoberg 2012; Frowd 2014; Wilcox 2017). My engagement with queer insights to interrogate the constitution of EU ontological security and b/ordering takes a different trajectory. By mobilising queer theory in conjunction with post/decolonial inquiry, I engage with developments in Queer International 
Relations scholarship which illustrate how the operations of international power are shaped by sexual norms and logics (Richter-Montpetit 2018, 222) and how these are co-imbricated with a host of other hierarchical categories, such as race, class and gender (Delatolla 2020; Rao 2020). In this sense, a queer analytic troubles and destabilises identities and binaries, constitutive of gender and sexualities and intersecting with wider relations of power, as these shape and are reproduced through national and transnational normative orders.

As an approach that refuses a clearly bound object, queer theory thus enables a critical engagement with regimes of normal, beyond the sexual(Richter-Montpetit 2018, 222). Informed by queer of colour critique, this includes tracing how gender and sexuality shapeshift in relation to other categories to produce regulatory and civilizational frames that pathologise a range of "deviant" others (Puar 2018; Manchanda 2015). By showing the contingent and political character of such norms, queer inquiry helps us trace the forms of violence and failure produced through the imposition of stable identities (Rossdale 2015, 378; Wilcox 2017). Queer post/decolonial scholarship alerts us to the complex ways in which figurations of failure are inflected with temporalities of lag and belatedness and projected onto spaces and communities at the margins of the international(Rao 2020; Clisby 2020; Kulpa and Mizielinska 2016). In doing so, this scholarship "provincialises" the Western grammar of modernity underpinning the international normative order, while also making visible how communities and subjects placed at geo-temporal margins navigate, exceed, and perhaps resist, their condition of relegation (see also Rao 2020, 26) Through a queer decolonial analytic, thus, we can explore the political potential of failure, in its temporal and spatial manifestations, to expose impossibly plural forms of being and (un)becoming that haunt and exceed normative mappings of the international.

Queering the logic of European integration reveals how, in spite of its configuration of a sui generis post-national model, narratives of Europeanisation that are central to crafting the EU's ontological security replicate the principle of sovereignty as authority of the political community, as always already constituted through gender and sexuality (Weber 2016, 148) and in its imbrication in race and Empire (Bhambra 2009). Theorised in in this way, European statecraft is mancraft. That is, it relies on and reproduces the gendered logics of man, as the liberal subject, white, sovereign, stable and 'knowable' in relation to perverse and/or normal gendered and sexualised figurations (Weber 2016, 4). Deploying a queer decolonial perspective, then, we can interrogate the operation of EU security as a regime of the normal that constitutes a coherent, stable and progressive self/space (Europe) through the production of perverse others, that "fail" to be knowable according to the seemingly singular EU logic of progress and security (Bosnia).

Analyses of Europeanisation and enlargement in the post-Yugoslav space demonstrate that since 2004 the promotion and diffusion of LGBT+ rights has emerged as a symbol of 
Europeanness, a clause of conditionality for enlargement in the region (Bilić 2016). Queerness, as attached to the legal framework of LGBTQ+ rights and EU conditionality, functions to uphold the EU's civilizational narrative that constitutes EUrope as an agent and space of progress and the Balkans as the targets of modernity, containment and domestication. ${ }^{v}$ The linkages between EUrope and the promotion of LGBT+ emancipation work as a form of homonationalism (Puar 2018) that, perhaps counterintuitively, reconstitutes the normative liberal foundations of Europe as a knowable and coherent space through the production of backward and racialised Balkan Others in need of civilization. LGBTQ+ rights become foot soldiers in the cartography of re-unifying EUrope and another terrain where anxieties about EU ontological security, stability and, crucially, Whiteness are manifested and negotiated (Rexhepi 2016) Mobilising a queer decolonial analytic thus spotlights the effects of colonial, racialised and (homo)normative logics undergirding the apparently benign myth of EU as a peace project and global security actor. It reveals how these logics are imbued with figurations of failure that obliterate complex lived experiences of communities constructed as objects and targets of EU security and spaces relegated to its periphery. Crucially, the intersection of queer theorising on failure and decolonial border thinking can also have a liberatory potential in exposing the limits of EU b/ordering that presuppose Europe as a singular, knowable, coherent political community and bounded space.

A number of interventions in queer theory and queer IR have focused specifically on rehabilitating failure as a figuration that resists disciplinary norms and perhaps offers new political imaginaries (Wilcox 2017; C. Weber 2014; Halberstam 2011; Love 2009). Queer theorist Jack Halberstam has been particularly concerned with turning on their head static models of success and failure underpinning life in the neoliberal age to explore the possibilities engendered by failure as a way of life (Halberstam 2011). Developing an archive anchored in sites of queer struggles and desires, Halberstam takes us on a journey through the impact, as well as rewards that failure can produce:

Under certain circumstances failing, losing, forgetting, unmaking, undoing, unbecoming, not knowing may in fact offer more creative, more cooperative, more surprising ways of being in the world".(Halberstam 2011, 3)

To be clear, this analytical move is not an attempt to provide better accounts of failure or to re-dress failure. Rather, Halberstam embarks in a sustained effort to show that exploring failure as way of life reveals murky and shady modes of undoing and unbecoming as subjectivities that, despite being discarded in binary models of success/failure, might offer alternative, more plural ways of inhabiting the world. For Halberstam, this entails recovering subjugated knowledges in the context of queer struggles: ways of being in the world that exceed an resit normative imperatives of successful life, i.e. masculinist, heteronormative, 
individualist, straight/forward(Halberstam 2011, 9-13). While failure comes with a host of negative and traumatic effects, Halberstam shows us, it also offers an opportunity to poke holes in the toxic positivity of contemporary life and the (western and colonial) liberal myths of inclusion, success, orderly and predictable adulthood that prop this social order. Zooming into failure, as enacted through figurations of the naive, the nonsensical, the foolish, the childish, Halberstam argues, can reveal both the inherent instability of norms that discipline certain modes of being in the world, as well as the potential of life otherwise (Halberstam 2011, 23-25).

While Halberstam's work is explicitly located in the exploration of queer identities, desires and sexuality, I argue that mobilising queerness and the queer art of failure in conjunction with decolonial border thinking offers a powerful approach to harness subjugated knowledges and spatio-temporal figurations that are discarded, erased and disqualified in normative narratives of EU peace and security. Bringing queer insights on failure to bear on decolonial mappings of the Southeast Europe region and Bosnia specifically opens a productive theoretical space to trouble the ways in which EU b/ordering secures normal spaces/subjects (EUrope) through the production of perverse spaces, such as Bosnia, conceived as objects of intervention, problems of security, sites in need of supervision, containment and domestication. Yet, by attending to Bosnia as a space that "fails", the contingency of EUrope as bounded space is exposed and more complex and plural spatiotemporal figurations come into focus. In the next section I discuss how aesthetics offers a particularly powerful approach to sense what is at stake in this site of b/ordering and explore failure's potential to reveal the instability of the EU's desire for ontological security.

\section{Undoing EUrope through Border Aesthetics.}

In this paper I mobilise queerness and the queer art of failure to explore spatio-temporal figurations enacted in the context of Bosnia's failed promises of peace that haunt and undo the foundational narratives underpinning EU security. I contend that aesthetic knowledges produced through cinema from/about Bosnia that engages with loss, failure and competing memories of war/peace afford us a creative entry point to uncover such figurations. Drawing upon critical scholarship in International Relations and Border Studies (Moore and Shepherd 2010; Lisle 2010; Hozić 2016; Steele 2016; Bleiker 2017; Choi 2018; Schimanski 2015; Brambilla 2015; dell'Agnese and Amilhat Szary 2015; Agathangelou and Ling 2009), I turn to aesthetics as a research ethos that can help us re-think security and border politics beyond the narrow convention of deterministic and state-centric approaches. Aesthetic politics in this paper refers not only to the cinematic process but rather to the kind of insights and sensibilities that artefacts, such as films, can facilitate (Bleiker 2017, 4). More specifically, aesthetic knowledge can help us challenge and re-imagine the stories we tell 
about Bosnia and the SEE region, as well as unsettle dominant security narratives of EUrope.

Following queer decolonial insights, I propose the films under examination as epistemological interventions that activate border thinking (Mignolo and Tlostanova 2006), displacing the universalising myth of European modernity and its border logic by bringing to the fore alternative, more complex and plural, ways of being and knowing. Through aesthetic language, cinema produces the border as it "scapes" its material and symbolic universe in ways that mirror, alter and possibly subvert existing imaginaries ( see also, dell'Agnese and Amilhat Szary 2015; Schimanski and Wolfe 2017). At the same time, cinema moves the audience emotionally and aesthetically in ways that can disrupt binary notions of inside/outside, here/there, us/them: by transporting the viewer to another time/place but also reinforcing the idea of the here and now (Stern 2010). Michael Shapiro proposes the notion of aesthetic subjects as figures that, through artistic genres such as cinema, can articulate such thinking (Shapiro 2012, 5). Aesthetic subjects are figures of multiple possibilities and orientations. Rather than stimulating critical thinking by inviting reflection on their inner lives, aesthetic subjects hold a creative and critical potential for how their trajectories of movement and interactions confront the viewer with insights about the world in which they belong(Shapiro 2012). As I will show in the film analysis, it is indeed through interactions and movements of bodies, and the stories they carry, that the borders of EUrope are performed, negotiated and undone, assuming multiple and often contradictory meanings that destabilise fixity, rationality and mimesis (dell'Agnese and Amilhat Szary 2015; Giudice and Giubilaro 2015).

Falling under "World cinema", a category constructed to identify minor film industries beyond Hollywood and for "Western" audiences, films from/about Bosnia must negotiate the "sticky" historical imprints of the mechanisms of relegation experienced in the region. To stay in circulation in the uneven terrain of global cinema, films that reflect on the Bosnian war have had to comply with the stereotypical imaginary of violent, conflict ridden Balkans that conforms to the expectations of Western markets and public (lordanova 2001). At the same time, as Dina lordanova points out, the creative industries of the region have sought to "capitalise on the togetherness that is bestowed on them and try to turn the undistinguished qualification of 'being Balkan' from liability into an asset" (lordanova 2006, 9). Films thus are powerful vehicles for creativity and self -expression that can challenge the boundaries of the visible and sayable through their aesthetic interventions. In this sense, I view "local" films as complex attempts by their makers to reflect on processes of memorialisation, trauma and loss in the region and, in doing so, undo the neat boundaries of what we term "EUrope". Activating aesthetic sensibilities they can disrupt how we feel, view and sense local 
war/peace experiences and taken for granted border imaginaries. On the one hand the documentary films I discuss in the paper might reproduce dominant imaginings of Bosnia rooted in the history of nationalist conflict and express longings for a Europeanness that is foreclosed. At the same time, they mobilise spatio-temporal figurations that exceed, undo and haunt the fixed borderlines of EUrope through their imaginative production and cinematic styles. Through a form of border aesthetics (Schimanski and Wolfe 2017) these films activate border thinking (Tlostanova, Thapar-Björkert, and Koobak 2016), stretching our imagination beyond the storyline and awakening new questions into EU border politics, past and present.

Presented within the Documentary Film competition programme at the Sarajevo Film Festival, the films I analyse in this paper are playful iterations of the genre in its traditional sense as they combine assemblages of live and archival footage, intertextual references through scenes cut-out of existing feature films, and repetition of screen shots. Even though with different styles (collage-like/vignette and personal memoir/narrative) and cinematographic effect (digital technology recording and analogue VHS recording) both films grapple with personal and collective memory of conflict, the (im)possibility of closure and Sarajevo's unresolved positioning within the European geopolitical imagination. Jasmila Žbanić's One Day in Sarajevo (2015) is a documentary film/project set on 28 June 2014, the 100th anniversary of the assassination of Franz Ferdinand, the heir to the throne of the Austro-Hungarian Empire, which sparked the First World War. As we know, the assassination and its anniversary are subjects of much controversy in Bosnia, Serbia and the rest of Europe, with interpretations embroiled in the divisive historical legacies in the region, national identity and victimhood, war memorialization and claims to Europeanness (Subotic 2017; Bartulović 2018). On the occasion of the centenary, a series of celebrations were held in Sarajevo, attracting a large and incongruent crowd made of EU officials and funders, tourists, fans of historic re-enactments, defenders and detractors of Princip, the Vienna Philharmonic Orchestra, as well as local Sarajevans who were involved in the frenzy of celebrations, got caught-up in the events or went about their daily lives. Narrating the events on that day through multiple viewpoints, the documentary mobilises thinking around the EU's grandiose attempts at memorialization and the complex border imaginaries and interlaced histories converging into the city.

Vladimr Tomic's Flotel Europa (2015) is part memoir, part coming of age tale and part documentary that takes us back to war-time Bosnia to recount personal experiences and memories of the director, part of his family and a larger community of Bosnians who fled besieged Sarajevo for Copenhagen. With the existing camps full, the Red Cross organised for a giant ship, uncannily named Flotel Europa, to be anchored in one of the canals. For two years the ship became the improbable home for a thousand Bosnians as they waited for the 
outcome of their asylum application. Conbining original VHS material recorded by the inhabitants of the Flotel, Tomic portrays the angst and joy of his adolescent years in the ship, as well as the different stories of the community who shared "the archipelago of exception"(Mendes and Sundholm 2015) with him. Attending to the cinematics imaginaries produced through the films, we can sense complex negotiations of failure and loss. I show how through an aesthetics of disorderly memories and subjects that might seem naive, nonsensical and "stuck" in (im)possible situations the films also "mount a cinematic challenge' (Shapiro 2012, 120) to the linearity, neat contours and false promises of EU peace and security and its attendant border logic.

\section{Aesthetics of disorientation: Or whose failure is it anyway?}

One day in Sarajevo engages with and disrupts one of the EU's foundational myths mobilised to craft its ontological security: Europe's long peace and the coherent narrative of a political community founded upon making war unthinkable(Mitzen 2018) As mentioned, Žbanić's documentary is a controversial play on the historic date that momentarily brought Sarajevo again at the centre of Europe's attention and out of the continuous relegation to its dysfunctional periphery: the $100^{\text {th }}$ anniversary of Franz Ferdinand's assassination, which shaped the history of modern Europe, and, crucially, also cemented the image of the Balkans as powder-keg in its periphery (Todorova 1997; Hammond 2005). Envisioned as a collective project, the film's production grapples with questions of discarded knowledges and the claiming of agency by giving the camera truly in the hands of $\mathrm{BiH}$ citizens, whom Žbanić invited to film their own versions and experiences on that day with small cameras and smartphones ${ }^{\mathrm{vi}}$. Informed by a mode of production that defies traditional genres of historical documentaries, as well as through its collage-like cinematography, the film mobilises border thinking by foregrounding interlaced histories produced through the failed promises and premises of the EU peace and security. Through scenes of slowness and foolishness emerging at this site of failure the film brings into focus alternative relations to temporality, linearity and neat memorialization, irreverently "poking holes" in the narratives of EUrope as a singular, coherent space and political community.

Narrated through shifting points of views and ambivalent perspectives, the anniversary celebrations become a catalyst for action and memory that recovers ambivalent, yet interlaced, experiences related to Sarajevo's contested history, its symbolic status as site of warfare, as well as on Bosnia-Herzegovina $(\mathrm{BiH})$ 's unresolved status in Europe. Not only we see footage of local (Bosnian Serb) people gathering to pray at Princip's memorial, there are those who travelled all the way to Sarajevo to either contest the commemoration or bring flowers to the site of the assassination. We see tourists of different nationalities visiting 
"the street corner that started the $20^{\text {th }}$ century"vii, tourist guides who explain the assassination in different languages and express different views on the Archduke, his assassin and hence the course of history. We see a protest by local activists against the hypocrisy behind "the mega event" that culminated in front of Sarajevo's City Hall, where European and local officials gathered to listen to a concert and celebrate European values (Bartulović 2018) pretending not to see the protesters outside. The documentary stubbornly re- inserts Sarajevo's life post-conflict and experiences of failure into a cartography of Europe, visualising complex intersections and tensions between local everyday experiences, national(ist) contentions and transnational imaginaries converging into the city. On one level, we could read the film as reconstituting aspirations to a familiar liberal narrative that seeks closure and inclusion in the European project, as if mourning a sense of Europeanness that is foreclosed for places that fail like Bosnia. However, what we sense through the film's border aesthetics are more ambivalent spatio-temporal figurations that disorient our geopolitical imagination and creatively disrupt the coherent workings of EU b/ordering.

Condensed in 60 minutes, Jasmila Žbanić and the Bosnian citizens who contributed to the film recover subjugated knowledges and disorderly memories converging into the city which haunt the coherent, yet violent, narrative of Europe's long peace as a foundational myth propping EU ontological security. The film's aesthetic borderwork continuously disorients the viewer through contradictory rhythms and apparently nonsensical interruptions that disrupt the solemnity and linearity of EU memorialization. Footage of the celebrations alternate with scenes of ordinary life in divided Sarajevo: a traditional wedding, kids playing outside, a father returning home for the summer with his two children to rediscover the city he left, presumably just after the war. Interspersed between the vignettes, war-time images of explosions in the besieged city appear at regular intervals interjecting the present with the unresolved and immanent legacy of war haunting the city and the EU's long peace. These scenes introduce a different rhythm that counters the frenzy of the celebrations and haunt the grandiose scene of memorialization. Through slowness and lack of sound these interjections express the stakes of failure as if invoking the weight of being pinned down by the legacy of conflict and perennial relegation at the periphery. However, failure mediated through slowness, silence and emptiness is ultimately productive for how the scenes rupture attempts to neat and coherent memorialization manifested in the anniversary celebration. Allowing us to sense experiences that, while disqualified in normative narratives of European peace and security, continue to haunt its borders, the cinematic borderscape unsettles the neat fantasy of European integration as a progressive narrative of making war unthinkable that works to contain Bosnia, and the wider SEE region, to its dysfunctional borderland. Queering the border through its camera work and montage, the film confront the audience with an impossibly plural and incoherent aesthetics of European history/present 
that disorients, unsettles and disorders, while also bringing to the fore local, everyday experiences as creative knowledges.

The actions of a character who "fails" to live up to the solemnity of the occasion through mockery and silliness introduce a tragi-comical challenge to the grandiose narratives of EU mastery and memorialization underpinning the centenary events. The inclusion of local conceptual artist Damir Nikšic works as the primary aesthetic subject in the film. We can read this character as the fool. Armed with a water pistol, he mimics the assassination by sprinkling the windscreens of cars passing by the spot where the historic murder took place. Dressed for the occasion in an immaculate white suit, he repeatedly disrupts the solemnity of the centenary acting in out of place, going in loops, cleaning the cars' windows, asking for money and bugging passers-by, making a mockery out of the event. Halberstam writes that silliness and loopy stupidity, as a profoundly gendered figuration, can also evoke queer temporalities and fluid ways of knowing that resist fixity, coherence and mastery(Halberstam 2011, 53-68). In the context of failure and EU b/ordering, the fool can be read as an ironic, yet serious, figuration that "works on and against" (Muñoz, 1999 cited in Tlostanova, Thapar-Björkert, and Koobak 2016) the binary of excessive and irrational Balkans vs. progressive rational Europe, which, as we know, is historically mediated through masculinity (Hansen 2013; Todorova 1997).

What we see at work through the fool is not necessarily a redemptive narrative of Balkan masculinity. Rather through looping, nonsense and mimicry the fool's actions disorient and "trick" the viewer leading to alternative ways of seeing and knowing the celebratory mis en scene that dispel taken for granted binaries. The fool here can be seen as a border persona, a trickster (Tlostanova, Thapar-Björkert, and Koobak 2016). It is precisely through his silly mimicry performance that the farcical and grotesque nature of the celebrations becomes apparent. Indeed, if we wanted, in the film's aesthetic borderscape all characters in the frenzy of celebrating appear disorderly and excessive, while the locals find ways of getting by in the slow violence of post-conflict everydayness. What is powerful in Žbanić's film is that these subjects inhabit interlaced histories, they are momentarily brought together in the same borderscape in ways that perhaps only aesthetic interventions can convey. In an interview, Žbanić suggested that rather than giving a message, One day in Sarajevo is a film that asks questions. viii In my reading, the film disorients our imagination that continuously relegate Post-Dayton Bosnia to the EU dysfunctional periphery. Through disorderly memories, "out of sync" characters and border aesthetics the film moves us to question taken for granted imaginaries that secure EUrope as a knowable space and coherent project of conflict resolution, progress and democracy. Disordering and "messing-up" this normative cartography, the film produces an aesthetic critique of European security and border politics 
by daring to us to ask: Whose conflict? Whose histories? Whose failures are we experiencing?

"I was a refugee": The spectre of war, debordering and the fantasy of "never again". Flotel Europe mobilises cinematic thinking about EU border politics, peace and security through a storyline about displacement and asylum set during the Bosnian war. As mentioned, the documentary makes visible the experiences of a community of Bosnian refugees who fled to Copenhagen to be hosted in a large boat. The documentary is a longstanding project of director Vladimir Tomic who spent two years in the Flotel with his older brother and mother. Tomic does not see the project as an activist intervention, rather he was moved to use his art to narrate and make sense of his family story and identity. ${ }^{\mathrm{ix}}$ In this sense, Flotel Europe might be less explicitly disruptive than Žbanić's film. Nevertheless, the documentary's political potential is articulated precisely by recovering personal/collective memories of the war that displace the EU narrative of Europe's long peace. Failure and loss in the film are enacted through scenes of mundanity and everydayness as dramas of adjustments (Berlant 2011) experienced by the protagonist, as a teenage boy, and the community of Bosnians who shared life in the Flotel. In my reading, part of the film's disruptive energy derives from the context of its screening in 2015 when the unfolding of the so-called refugee crisis evoked linkages between current experiences of displacement and migration and those of the 1990s.

The documentary is primarily a story about Vladimir's experiences of displacement and containment as a young teenage boy. This dimension adds interesting layers to thinking about failure. Halberstam writes that figurations of childhood are imbued with anarchic and queer energy in the sense that children are open to multiple possibilities(Halberstam 2011, 27-28). In Flotel Europe, Vladimir's coming of age experiences work creatively to introduce a quasi-comic register in the midst of the harsh and challenging reality of the asylum procedure and the dramatic news arriving from the frontline. We see Vladimir's teenage boredom and goofiness. We follow him grappling with expectations of growing up and measuring himself against Boško Buha, the young Yugoslav martyr. ${ }^{\times}$We see Vladimir falling in love with a girl who ends up kissing his best friend. Through his teenage disappointments and unrequited love that don't live up to normative expectations of becoming a man, we also see a glimpse of optimism that blurs the boundaries between winners and losers, showing how the story of failure and loss is also a story of surviving and keeping going in compromised conditions of existence. Crucially, it is through Vladimir's teenage eyes that we, as viewers, encounter the universe he inhabits in the Flotel and sense the border negotiations at stake in the film. 
In a similar vein to Žbanić's film, Tomic's memoir goes to the heart of EU anxieties and tensions about peace and security which have long been manifested in the context of the Yugoslav Wars and more recently in the context of migration control. Taking us back to the 1990s, the documentary spotlights the moment that shattered the narrative of Europe's long peace (Manners and Murray 2016) through the spectre of war embodied by the community of refugees. The film enacts a complex border aesthetics as the protagonists grapple with their unintelligible position in the boat, uncannily named "Europe", in the European city of Copenhagen, and in relation to the place they once called home, Yugoslavia. We bear witness to everyday struggles and sense of failure as the protagonists await to be granted asylum and ,thus, to be acknowledged. A deep sense of nostalgia imbues the film as the characters we encounter experience the shattering of Yugoslav bonds and borders. Loss and failure are mediated through the protagonists' painful, as well as creative, negotiations of this (im)possible situation. Gradually, the Flotel reflects the tensions, losses and divisions that are happening in the frontline, but also becomes a liminal space of exception produced through migration and asylum control. The film's border aesthetics thus is deeply entangled with the contentious politics of the war and with its reverberations into EUrope, disordering its foundational narrative of making war unthinkable (Mitzen 2018) through the experiences carried by the community of Bosnian refugees. As we follow the protagonists' worsening conditions in the flotel, the deadly contradictions between narratives of Europe as a peace project and the treatment of refugees become apparent: the experiences of abandonment destabilise this narrative, revealing the precariousness of universalising norms of peace and security, and their success. And yet, life in the Flotel goes on: in a similar vein to Žbanić's production, the Flotel inhabitants find in the VHS cameras a way to record their (im)possible situation, momentarily outliving stasis, immobility and abandonment through their creativity.

Even though the director had been working on the documentary since $2012^{x i}$, the film's disruptive energy was amplified from the context of its screening, in 2015, when migration and the influx of refugees sparked renewed anxieties about EU ontological security and the intensification of the militarised border regime. In this context, the cinematic borderscape can be read beyond the specificity of the Bosnian War to suddenly assume a new, current relevance. This re-orientation is achieved through the community of Bosnians that we encounter through Vladimir's narrative. Perhaps counterintuitively, the everydayness conveyed in the film works to stretch our imagination beyond the specificity of the storyline. Viewed in the context of the unfolding refugee "crisis", mundane scenes and atmospheres evoked through the omnipresent boat, the waiting around, the routine strategies deployed by the Flotel inhabitants to resume "normal life" are infused with a powerful energy that mobilises border thinking. As the documentary premièred at the Sarajevo Film Festival in 
2015, these scenes mobilise an aesthetic sensibility that exceed normative mappings, orienting us/viewers towards images and visual worlds circulated around the so called "refugee and migration crisis".

These spatio-temporal connections were evoked in the SFF's programme where Flotel Europe and One Day in Sarajevo were included under a series titled "Taking down the fences". Curated by festival organisers, the series brought together films on migration and human rights which explicitly made linkages between the SEE region and the ongoing situation in the Mediterranean, with the aim of encouraging reflections on the so-called crisis among Festival participants, media and audience. ${ }^{\text {ii }}$ In the political context of 2015, Flotel Europe's border aesthetics activated attachments between experiences of exile and displacement in the post-Yugoslav borderlands and "other peripheries", evoking connections that were happening off screen when refugees and migrants had begun to follow the socalled Balkan route and when some people in Bosnia had started to mobilise in solidarity. Similar connections between the film and the ongoing refugee crisis were also subsequently made in film reviews and interviews with the director. xiii The spatio-temporal figurations that come into focus through Flotel Europe's screening are thus excessive and politically disruptive, revealing continuities in the experiences of displacement and interlaced histories that are obscured in normative narratives that seek to fix EUrope as a coherent space of progress, peace and security. As Jeandesboz and Pallister-Wilkins argue in relation to Mediterranean border politics and security, the invocation of a crisis:

"limits our view and masks the structural politics behind the 'migration crisis'. It obscures the violence of territorial borders more broadly and the European border regime more specifically that work to constantly and routinely reproduce Europe as an exclusive space $(2016,318)$.

Bordering processes in the 1990s and the current EU border regime are inflected through different political dynamics, policies and migration patterns. Yet, the screening of Flotel Europe in 2015 works to activate "intertwined peripheral connections" (Kušić, Lottholz, and Manolova 2019) through experiences of displacement and abandonment, laying bare ongoing tensions between the narrative of "never again"(Della Sala 2018), a key foundational myth of EU peace and security emphatically re-embraced by EUrope in the aftermath of the Yugoslav wars, and the contemporary narratives of crisis and emergency mobilised to seal and control EU borders.

\section{Conclusion}

The militarised border and security regime we have witnessed intensify as a result of refugee influx has been described as both symptom of and response to multiple crises besetting EU institutions, borders and sense of community. Scholars working on the notion 
of ontological security have suggested understanding these security practices as mechanisms of anxiety management activated in response to key stressors that seek to unbound and undermine the EU's coherent identity as a peace project, security actor and political community. The intersection of decolonial scholarship and queer analysis enables us to move away from the logic of exception and self-referential existential crisis by drawing attention to the sustained and multifaceted violence inherent to the seemingly progressive logic of EU border politics and security from the perspective of its Others, conceived as targets of enlargement, peacebuilding and neighbourhood policies and/or security threats that attempt to undermine its borders. Rather, this approach allows us to problematise this anxious and violent labour as always, already constitutive of the gendered, homonormative and racialised narratives and b/ordering practices that seek to anchor the EU's identity through the production of places that fail to be knowable and governable according to universalising norms.

I have proposed decentring and queering EU security and b/ordering from the perspective of spaces with a long history of being a target of EU peace and security practices, like the SEE region and Bosnia specifically, which have recently re-entered the spotlight in contemporary debates over the EU's border regime. Echoes of the complex border politics of the region and wider contentions over EU narratives of peace and security entered the 2015 edition of the Sarajevo Film Festival where film makers and festival organisers created an opportunity to raise critical questions about EU border politics through the medium of cinema. In this paper, I start from the premise that aesthetic politics enables us 'to find new ways of thinking, seeing, hearing and sensing the political' (Bleiker 2017, 5) offering insights we would not otherwise achieve. I have thus proposed the festival as a productive entry point to explore, through films from/about the region, what is at stake for communities that have experienced failure in this marginal, yet often pivotal space for the EU geopolitical imagination. I have argued that through cinematic knowledge that centres the perspectives of communities conceived as "Other" we can harness powerful insights into EU border politics and security beyond institutional and normative approaches.

I have foregrounded two documentaries as creative interventions that, rooted in the complex historicity of Bosnia as a space that fails, mobilise border thinking that disrupts EU cartographies and norms. Both documentaries were screened at a moment when the complex history of loss, war and marginalisation of the region regained prominence within ongoing anxieties about EU security and its crisis, manifested as much in attempts to exploit the centenary of Franz Ferdinand's assassination to reassert the EU's progressive values of peace and reconciliation, as in the militarised spectacle of border security that ensued around the se-called refugee crisis. Viewed in this political context, the two documentaries are powerful epistemological interventions that cast a critical eye on 
narratives of crisis and exception mobilised to frame current EU border politics by confronting us with critical imaginaries of the deadening effects of the seemingly benign logic of EU peace and security, and their duress. Through an aesthetics of disorderly memories and complex border imaginaries the documentaries are creative interventions that re-centre histories of loss and failure, but also endurance and survival in compromised conditions of existence from the perspective of communities conceived as "Other." Activating border thinking and peripheral connections enabled by the political context of their screening, the films ultimately can be read as source of inspiration for how they articulate more complicatedly human stories of war, failure and displacement, gesturing to plurality, commonalities and fragile solidarities as alternatives that are constantly under erasure in narratives that seek to secure Europe as a singular, coherent and, ultimately, exclusive space.

\section{Acknowledgments}

I wish to thank Shine Choi, Noirin MacNamara and Jamie Hagen for offering invaluable feedback on earlier drafts of this project. Many thanks to Caron Gentry and Laura Mills as editors of this Special issue and to the two anonymous reviewers for their productive comments and generous feedback. I am also grateful to Vladimir Tomic for taking the time to answer my questions about the making of Flotel Europe.

\section{References}

Agathangelou, Anna M., and L. H. M. Ling. 2009. Transforming World Politics: From Empire to Multiple Worlds. 1 edition. London; New York: Routledge.

Agnese, Elena dell', and Anne-Laure Amilhat Szary. 2015. 'Borderscapes: From Border Landscapes to Border Aesthetics'. Geopolitics 20 (1): 4-13. https://doi.org/10.1080/14650045.2015.1014284.

Baker, Catherine. 2018. Race and the Yugoslav Region: Postsocialist, Post-Conflict, Postcolonial? Manchester: Manchester University Press.

Bartulović, Alenka. 2018. 'Tourism, Politics And Alternative Engagements With The Memory Of The Sarajevo Assassination In Post-War Bosnia-Herzegovina'. Traditiones 47 (1): 169-91.

Berlant, Lauren. 2011. Cruel Optimism. Durham: Duke University Press.

Bhambra, Gurminder K. 2009. 'Postcolonial Europe, or Understanding Europe in Times of the Postcolonial'. Sage Handbook of European Studies. London: Sage, 69-85. 2017. 'Postcolonial Europe: Afterword'. Postcolonial Europe: Comparative Reflections after the Empires, 215.

Bialasiewicz, Luiza, ed. 2011. Europe in the World: EU Geopolitics and the Making of European Space. Critical Geopolitics. Farnham, Surrey, England ; Burlington, VT: Ashgate. http://encore.qub.ac.uk/iii/encore_qub/record/C_Rb1896991_Seu\%20space\%20_ Orightresult_U_ $\mathrm{X} 2$ ?lang=eng\&suite $=q u b$.

Bilić, Bojan. 2016. LGBT Activism and Europeanisation in the Post-Yugoslav Space: On the Rainbow Way to Europe. Springer. 
Bjelic, Dusan I., and Obrad Savic. 2005. Balkan as Metaphor: Between Globalization and Fragmentation. New Ed edition. Cambridge, Mass.: MIT Press.

Bleiker, Roland. 2017. 'In Search of Thinking Space: Reflections on the Aesthetic Turn in International Political Theory'. Millennium, January, 0305829816684262. https://doi.org/10.1177/0305829816684262.

Brambilla, Chiara. 2015. 'Navigating the Euro/African Border and Migration Nexus Through the Borderscapes Lens: Insights from the LampedusalnFestival'. Borderscaping: Imaginations and Practices of Border Making, 111.

Chakrabarty, Dipesh. 2009. Provincializing Europe: Postcolonial Thought and Historical Difference..

Choi, Shine. 2018. 'Borders'. In Visual Global Politics, edited by Roland Bleiker, 35-41. Routledge.

Choi, Shine, and Maria-Adriana Deiana. 2017. 'Questioning the International: (Un)Making Bosnian and Korean Conflicts, Cinematically'. Trans-Humanities Journal 10 (1): 530. https://doi.org/10.1353/trh.2017.0000.

Clisby, Suzanne. 2020. Gender, Sexuality and Identities of the Borderlands: Queering the Margins. Routledge.

Delatolla, Andrew. 2020. 'Sexuality as a Standard of Civilization: Historicizing (Homo)Colonial Intersections of Race, Gender, and Class'. International Studies Quarterly 64 (1): 148-58. https://doi.org/10.1093/isq/sqz095.

Della Sala, Vincent. 2018. 'Narrating Europe: The EU's Ontological Security Dilemma'. European Security 27 (3): 266-279.

Frowd, Philippe M. 2014. 'State Personhood, Abjection and the United States' HIV Travel Ban'. Millennium 42 (3): 860-78. https://doi.org/10.1177/0305829814541321.

Gilbert, Andrew, and Jasmin Mujanović. 2016. 'Dayton at Twenty: Towards New Politics in Bosnia-Herzegovina'. Southeast European and Black Sea Studies, 1-6.

Giudice, Cristina, and Chiara Giubilaro. 2015. 'Re-Imagining the Border: Border Art as a Space of Critical Imagination and Creative Resistance'. Geopolitics 20 (1): 79-94. https://doi.org/10.1080/14650045.2014.896791.

Gordy, Eric. 2015. 'Dayton's Annex 4 Constitution at 20: Political Stalemate, Public Dissatisfaction and the Rebirth of Self-Organisation'. Southeast European and Black Sea Studies 15 (4): 611-22. https://doi.org/10.1080/14683857.2015.1134132.

Haahr, Jens Henrik, and William Walters. 2004. Governing Europe: Discourse, Governmentality and European Integration. Routledge.

Halberstam, Jack. 2011. The Queer Art of Failure. Duke University Press. https://books.google.co.uk/books?hl=en\&lr=\&id=dwdYVrSbupcC\&oi=fnd\&pg=PP8\&d $\mathrm{q}=\mathrm{J}+$ halberstam\&ots=aINRFucfiY\&sig=sW_LUpT3vmCoLx1JOVY3D3dKb3E.

Hammond, Andrew. 2005. "The Danger Zone of Europe" Balkanism between the Cold War and 9/11'. European Journal of Cultural Studies 8 (2): 135-54. https://doi.org/10.1177/1367549405051841.

Hansen, Lene. 2013. Security as Practice: Discourse Analysis and the Bosnian War. Routledge.

Horvat, Srecko, and Igor Štiks. 2012. 'Welcome to the Desert of Transition! Post-Socialism, the European Union, and a New Left in the Balkans'. Monthly Review 63 (10): 38.

Hozić, Aida A. 2016. 'Introduction: The Aesthetic Turn at 15 (Legacies, Limits and Prospects)'. Millennium, December, 0305829816684253. https://doi.org/10.1177/0305829816684253.

lordanova, Dina. 2001. Cinema of Flames: Balkan Film, Culture and the Media / Dina lordanova.

http://encore.qub.ac.uk/iii/encore_qub/record/C Dina_Orightresult_ X4?lang $=$ eng\&suite $=q u b$. 2006. The Cinema of the Balkans. Wallflower Press.

Jeandesboz, Julien, and Polly Pallister-Wilkins. 2016. 'Crisis, Routine, Consolidation: The Politics of the Mediterranean Migration Crisis'. Mediterranean Politics 21 (2): 316-20. https://doi.org/10.1080/13629395.2016.1145825. 
Kahlina, Katja. 2015. 'Local Histories, European LGBT Designs: Sexual Citizenship, Nationalism, and "Europeanisation" in Post-Yugoslav Croatia and Serbia'. Women's Studies International Forum 49 (March): 73-83. https://doi.org/10.1016/j.wsif.2014.07.006.

Kinnvall, Catarina. 2016. 'The Postcolonial Has Moved into Europe: Bordering, Security and Ethno-Cultural Belonging'. JCMS: Journal of Common Market Studies 54 (1): 152168.

Kinnvall, Catarina, lan Manners, and Jennifer Mitzen. 2018. 'Introduction to 2018 Special Issue of European Security: "Ontological (in)Security in the European Union"'. European Security 27 (3): 249-65. https://doi.org/10.1080/09662839.2018.1497977.

Kotecki, Kristine. 2014. 'Europeanizing the Balkans at the Sarajevo Film Festival'. Journal of Narrative Theory 44 (3): 344-366.

Kovacevic, Natasa. 2009. Narrating Post/Communism: Colonial Discourse and Europe's Borderline Civilization. London; New York: Routledge.

Kulpa, Robert, and Joanna Mizielinska. 2016. De-Centring Western Sexualities: Central and Eastern European Perspectives. Routledge.

Kušić, Katarina, Philipp Lottholz, and Polina Manolova. 2019. 'Dversia's Special Issue in English: Decolonial Theory \& Practice in Southeast Europe'. DВЕРСИЯ, March. http://dversia.net/4644/dversia-decolonial-theory-practice-southeast-europe/.

Lisle, Debbie. 2010. 'The Art of International Relations'. International Studies Review 12 (4): 656-57. https://doi.org/10.1111/j.1468-2486.2010.00978.x.

Love, Heather. 2009. Feeling Backward. Harvard University Press.

Majstorović, Danijela, Zoran Vučkovac, and Anđela Pepić. 2015. 'From Dayton to Brussels via Tuzla: Post-2014 Economic Restructuring as Europeanization Discourse/Practice in Bosnia and Herzegovina'. Southeast European and Black Sea Studies 15 (4): 661-82. https://doi.org/10.1080/14683857.2015.1126093.

Manchanda, Nivi. 2015. 'Queering the Pashtun: Afghan Sexuality in the Homo-Nationalist Imaginary'. Third World Quarterly 36 (1): 130-46. https://doi.org/10.1080/01436597.2014.974378.

Manners, Ian, and Philomena Murray. 2016. 'The End of a Noble Narrative? European Integration Narratives after the Nobel Peace Prize'. JCMS: Journal of Common Market Studies 54 (1): 185-202.

Mendes, Ana Cristina, and John Sundholm. 2015. 'Walls and Fortresses: Borderscapes and the Cinematic Imaginary'. Transnational Cinemas 6 (2): 117-22. https://doi.org/10.1080/20403526.2015.1073490.

Mignolo, Walter D., and Madina V. Tlostanova. 2006. 'Theorizing from the Borders: Shifting to Geo- and Body-Politics of Knowledge'. European Journal of Social Theory 9 (2): 205-21. https://doi.org/10.1177/1368431006063333.

Mitzen, Jennifer. 2018. 'Anxious Community: EU as (in)Security Community'. European Security 27 (3): 393-413. https://doi.org/10.1080/09662839.2018.1497985.

Moore, Cerwyn, and Laura J. Shepherd. 2010. 'Aesthetics and International Relations: Towards a Global Politics'. Global Society 24 (3): 299-309. https://doi.org/10.1080/13600826.2010.485564.

Puar, Jasbir K. 2018. Terrorist Assemblages: Homonationalism in Queer Times. Duke University Press.

Rao, Rahul. 2020. Out of Time: The Queer Politics of Postcoloniality. Oxford University Press.

Rexhepi, Piro. 2016. 'From Orientalism to Homonationalism: Queer Politics, Islamophobia and Europeanization in Kosovo'. Southeastern Europe 40 (1): 32-53. https://doi.org/10.1163/18763332-03903014.

Richter-Montpetit, Melanie. 2018. 'Everything You Always Wanted to Know about Sex (in IR) but Were Afraid to Ask: The 'Queer Turn'in International Relations'. Millennium 46 (2): $220-240$.

Rossdale, Chris. 2015. 'Enclosing Critique: The Limits of Ontological Security'. International Political Sociology 9 (4): 369-86. https://doi.org/10.1111/ips.12103. 
Rumelili, Bahar. 2018. 'Breaking with Europe's Pasts: Memory, Reconciliation, and Ontological (In)Security'. European Security 27 (3): 280-95.

https://doi.org/10.1080/09662839.2018.1497979.

Schimanski, Johan. 2015. 'Border Aesthetics and Cultural Distancing in the NorwegianRussian Borderscape'. Geopolitics 20 (1): 35-55. https://doi.org/10.1080/14650045.2014.884562.

Schimanski, Johan, and Stephen F. Wolfe, eds. 2017. Border Aesthetics: Concepts and Intersections. 1 edition. New York, NY Oxford: Berghahn Books.

Shapiro, Michael J. 2012. Studies in Trans-Disciplinary Method: After the Aesthetic Turn. Routledge.

Shepherd, Laura J., and Laura Sjoberg. 2012. 'Trans- Bodies in/of War(s): Cisprivilege and Contemporary Security Strategy'. Feminist Review, no. 101: 5-23.

Slootmaeckers, Koen. 2019. 'Constructing European Union Identity through LGBT Equality Promotion: Crises and Shifting Othering Processes in the European Union Enlargement'. Political Studies Review, 1478929919877624.

Steele, Brent J. 2016. 'Recognising, and Realising, the Promise of The Aesthetic Turn'. Millennium, December, 0305829816684254. https://doi.org/10.1177/0305829816684254.

Stern, Lesley. 2010. 'How Movies Move (between Hon-Kong and Bulawayo, between Screen Nd Stage)'. In Wolrd Cinema, Trasnational Perspectives, edited by Nataša Durovicová and Kathleen Newman. Routledge.

Subotic, Jelena. 2017. 'Terrorists Are Other People: Contested Memory of the 1914 Sarajevo Assassination - Subotić'. Australian Journal of Politics and History 63 (3): 369-81.

2018. 'Political Memory, Ontological Security, and Holocaust Remembrance in PostCommunist Europe'. European Security 27 (3): 296-313. https://doi.org/10.1080/09662839.2018.1497980.

Tlostanova, Madina, Suruchi Thapar-Björkert, and Redi Koobak. 2016. 'Border Thinking and Disidentification: Postcolonial and Postsocialist Feminist Dialogues'. Feminist Theory 17 (2): 211-228.

Todorova, Maria Nikolaeva. 1997. Imagining the Balkans. New York; Oxford: Oxford University Press.

Van Houtum, Henk, Olivier Thomas Kramsch, and Wolfgang Zierhofer. 2005. B/Ordering Space. Ashgate Aldershot. http://henkvanhoutum.nl/wpcontent/uploads/2013/05/borderingspace.pdf.

Weber, Cynthia. 2014. 'Why Is There No Queer International Theory?' European Journal of International Relations, April. https://doi.org/10.1177/1354066114524236.

Weber, Cynthia. 2016. Queer International Relations: Sovereignty, Sexuality and the Will to Knowledge. Oxford University Press.

Wilcox, Lauren. 2017. 'Practising Gender, Queering Theory'. Review of International Studies 43 (5): 789-808. https://doi.org/10.1017/S0260210517000183.

Wolff, Larry. 1994. Inventing Eastern Europe: The Map of Civilization on the Mind of the Enlightenment / Larry Wolff. Stanford, Calif. : Stanford University Press,...

\footnotetext{
i Drawing upon political geography and critical border studies, the term EUrope I deploy in the paper refers to the spatial imaginations underpinning Europeanisation as the process of making European spaces through various technologies of b/ordering. (see for example Bialasiewicz 2011; Haahr and Walters 2004; Van Houtum, Kramsch, and Zierhofer 2005). It also draws attention to bordering processes that "fix" the idea of Europe as space of progress, peace and human rights masking its exclusionary politics and colonial legacies.

ii I use the term Southeast Europe to identify both a geographical space encompassing the former Yugoslav republics, Albania, Romania, Bulgaria, and to some extent Turkey, Cyprus, Greece, as well as a peripheral site cemented in the European geopolitical imagination through histories of
} 
domination in the Ottoman empire, post-socialist transformations and dysfunctional polities as EU member states and borderlands.

iii For examples of the production of Bosnia as a danger zone of Europe see (Hammond 2005)

iv A poignant example is the mission statement of the EU delegation in $\mathrm{BIH}$, where the supervisory, yet neutral, role of the EU is continuously highlighted in spite of deadlock and impasse: "Bosnia and Herzegovina: united, peaceful, prosperous and a future Member State of the European Union. We share these aspirations of the citizens of Bosnia and Herzegovina. Combining the resources of the European Union, we are assisting the institutions at all levels, the business community, civil society and citizens to make this EU future happen" EU Delegation to Bosnia and Herzegovina mission statement, http://europa.bal (accessed 21 December 2019)

$\checkmark$ Queer scholarship on Europeanisation in the post-Yugoslav space has produced fruitful analyses of the ambivalent linkages between EU enlargement and LGBT+ emancipatory politics (see also Kahlina 2015; Slootmaeckers 2019)

vi She included instructions for the project in a Facebook page, asking submissions to be accompanied with an explanation of the kind of experiences and atmospheres that people wanted to capture with the video material.

vii Slogan used for the occasion.

viiilnterview with Jasmila Žbanić', Bergamo Film Festival, available at https://www.youtube.com/watch?v=eY8jYQxlkjw

ix Personal email conversation with Vladimir Tomic, 06/11/2019

× The documentary includes scenes from Branko Bauer's 1978 fiction film about the young partisan.

xi Personal email conversation with Vladimir Tomic 6/11/2019.

xii As stated in the $21^{\text {st }}$ Sarajevo Film Festival official guide, p.55.

xiii See for example: Alan Meban, "Flotel Europa - footage from 20 years ago that speaks to the refugee crisis today,: https://focusonrefugees.org/flotel-europa-footage-from-20-years-ago-thatspeaks-to-the-refugee-crisis-todayl; Director talk Vladimir Tomic, https://www.youtube.com/watch?time continue=93\&v=TOVsBFbIXAE 